\title{
Possible effects of economy digitalization processes on Russian mining industry from economic theory point of view
}

\author{
M. Khaikin \\ Doctor of Economics, Professor, Department of Economic Theory, Saint Petersburg Mining University, \\ Saint-Petersburg, Russian Federation \\ M. Shabalov \\ PhD, Associate Professor, Department of Economics, Accounting and Finance, Saint Petersburg Mining \\ University, Saint-Petersburg, Russian Federation \\ D. Ivanova \\ PhD student, Department of Economics, Accounting and Finance, Saint Petersburg Mining University, \\ Saint-Petersburg, Russian Federation
}

\author{
N.A. Shapiro \\ Doctor of Economics, Professor, ITMO University
}

\begin{abstract}
The subject of discussion in the article are the results of the study presented in the World Bank reports (World Development Report-2016: Digital Dividends and Reaping Digital Dividends: Leveraging the Internet for Development in Europe and Central Asia, 2017) devoted to the development of the digital economy in the modern world; the main conclusions of the reports projected on the sphere of mineral resources management are presented. The scope of the dynamic development of the digital economy and the economic effects of its successful use in developed countries have provided leading countries with high development indicators. Possible prospects and threats for those countries that are behind in the development of the digital economy are presented, attention is focused on the relationship between the digital and the old (analogue) economies as well as on the need to improve its institutions, and economic policy directions. The article raises a number of theoretical and economic aspects related to both the change in the well-known ideas about the asymmetry of information and the problem of the cost of information itself in the digital economy. The sphere of mineral resources management and the inevitable objective changes and threats associated with the underestimation of the digital economy role in this segment are considered through the main characteristics of the digital economy. Attention is focused on the urgency of the development problems of the digital economy in the field of mineral resources management, the role of the state in this process is indicated.
\end{abstract}

Keywords: information and communication technologies (ICT), digital economy, digitalization process, analogue environment, mineral resources management, competitiveness, digital money

\section{INTRODUCTION}

The real content of the concept of the digital economy is rapidly expanding, changing and complementing.

The term "digital economy", first used by Nicholas Negroponte (University of Massachusetts) in 1995 to explain the advantages of a new profitable segment in the economy, emerging 
on the basis of information and communication technologies (ICT), compared with the old (analogue) economy, today can be interpreted much broader.

The initial version of the concept included electronic business (e-business) and electronic commerce (e-commerce), electronic goods (e-goods) and services produced and sold by these means and, as a rule, with the use of electronic money (e-money/digital money). This was followed by the expansion of the e-business opportunities use through the financial sector, as well as traditional production, which has a "physical" embodiment of goods and services (weight, raw materials, transportation processes). Another segment of the digital economy has become the non-market sector of health care services, education, public administration, etc. (Bowers M.R. 2017).

This article is intended to consider effects of the digital economy introduction into one of the most traditional sectors of economic activity - mineral resources management.

\section{LITERATURE REVIEW}

Despite the high level of development of the digitalization topic in certain technical aspects of mineral resources management (Gogolinskiy et al. 2019; Bazhin et al. 2018; Trushko V. L. et al. 2019), there are practically no papers on this subject generally recognized by the scientific community (if we consider high citation in international databases like Scopus, Web of Science, etc. as the modern recognition criteria). Moreover, there are of an order of magnitude more articles and notes in the media, as well as in the advertising and analytical departments of large consulting companies (Durrant-Whyte 2017; Schneider 2018). The gap between the scientific community and business in the field of mineral resources management, unfortunately, is very characteristic for the modern world, but it can in no way be considered normal.

If we leave aside the issue of mineral resources management, we can state that a lot of research has been carried out, both on the digital economy as a whole and on its individual components. A large number of publications is related to the impact of ICT on labor productivity (Kretschmer 2013; Czernich, 2011), as well as on economic growth in general (Latif 2018; Prieger 2013; Gruber 2014).

The importance of understanding the role of the digital economy in the modern world is supported by the fact that the World Bank regularly publishes reports on this area (World Development Report. Digital Dividends, 2016; Reaping Digital Dividends: Leveraging the Internet for Development in Europe and Central Asia, 2017). The competitiveness and the potential of the development of the digital economy are described in a comprehensive study covering 60 countries - Digital Evolution Index - 2017.

Defining the digital economy "here and now", it should be recognized that the digital economy is not only an activity directly related to the further development of provision services of electronic payments, online trading, crowdfunding and other digital technologies, but also a widespread adoption of existing techniques in traditional areas of the economy (Revenko, 2017).

The wide and successful "digitization" in a number of countries brought tangible positive economic results, affected the growth rate of GDP, the increase in the number of jobs, and the quality and speed of service delivery.

In countries with advanced digitalization, there is a real opportunity to influence the effectiveness of international trade by adjusting existing rules (Crozet 2016), improve cross-border trade in an integration union (Gomez-Herrera 2013), improve labor market mechanisms (Vazquez 2017), composition and the structure of jobs (Lewandowski 2016), assess the quality of jobs (Autor 2013), help remove internal obstacles for company development (Paunov 2015), optimize the costs of logistics firms and budget organizations (Loch et al. 2008), etc.

For countries with a low level of ITC development, researchers predict various - depending on the areas of operation - effects in further digitalization progress. For example, dependence was found in exports and imports - a 10\% increase in the number of Internet users in individual countries led to an increase in trade between these countries by $0.6 \%$. Traditional industries that have never been previously associated with digitalization were analyzed in detail, 
and it turned out that $75 \%$ of the total economic impact of Internet technologies was obtained in such industries.

Thus, based on the positive practices of the digital economy, the formation of a influence instruments portfolio has already started in the scientific literature, both at the micro and macro levels of economic development.

\section{METHODOLOGY}

To study the state of mineral resources management in the context of the development of the digital economy, a set of methods is used, such as descriptive analysis, a comparative results analysis of successful and problematic practices of the digital economy and its relationship with mineral resources management. Some well-known economic deductive hypotheses about the asymmetry of information used in microeconomics are interpreted and the macroeconomic hypothesis about the nature of money and its properties is interpreted.

The empirical basis of the study were the materials of two reports of the World Bank (2016, 2017) devoted to the problems of the digital economy, as well as data from the Digital Evolution Index - 2017.

The results of the study represent the authors' judgments about the relatively immediate prospects for the development of the digital economy in the field of mineral resources management, the advantages and issues of the development of mineral resources management, depending on the level and pace of implementation of the digital economy in this area. It is shown that a misunderstanding of the digital economy advantages in the field of mineral resources management can lead to inadequate assessments of the country's ability of geological studies, exploration and mining in world markets.

The basis of the scientific soundness of the article is representativeness, reliability and consistency of data provided by competent world institutions, as well as building the authors' reasoning on the ideas and views of recognized scientists and experts in the field of digitalization and subsoil use.

\section{ANALYTICAL PART}

\subsection{Possible threats of digitalization to developing countries.}

The rapid expansion of the digital economy is just as rapidly making adjustments to assessing accumulated experience and recommendations for those countries that are starting to work, or those that are trying to improve their results in the development of the digital economy today (Table 1).

The Digital Evolution Index - 2017 uses 170 parameters that describe 4 main factors that determine the rate of digitalization:

1) level of supply (Internet access and infrastructure development, as international studies show, more than half of the world's population use the Internet);

2) level of demand for digital technologies;

3) institutional environment (government policy, legislation, resources);

4) innovative climate (investments in $\mathrm{R} \& \mathrm{D}$ and digital startups).

In addition to a slowdown, i.e. investing in the development of methods of the digital economy itself and its distribution in the modern dynamic and unstable world, even the digital economy itself cannot avoid risks. The risks of the digital economy are associated with the criminal use of its own achievements, creating cyber threats, such as cyber fraud, "digital slavery", "digital gap", etc.

Practical measures arising from the experience of today's and yesterday's leaders in overcoming risks and confronting threats are as follows. 
Table 1. State and growth rate of the digital economy in 2017. Compiled by the authors based on http://web-payment.ru/article/250/top-10-cifrovaya-ekonomika/.

\begin{tabular}{|c|c|c|}
\hline Group of countries & Characteristics & Examples \\
\hline Leading countries & $\begin{array}{l}\text { demonstrate high rates of digital devel- } \\
\text { opment, maintain it and continue to } \\
\text { lead in the diffusion of innovation. }\end{array}$ & $\begin{array}{l}\text { Singapore, the United Kingdom, New } \\
\text { Zealand, the United Arab Emirates, } \\
\text { Estonia, Hong Kong, Japan and Israel }\end{array}$ \\
\hline $\begin{array}{l}\text { Countries slowing } \\
\text { down the digital } \\
\text { economy }\end{array}$ & $\begin{array}{l}\text { for a long time they have shown steady } \\
\text { growth, but now without the introduc- } \\
\text { tion of innovations they run the risk of } \\
\text { lagging behind the leaders of } \\
\text { digitalization }\end{array}$ & $\begin{array}{l}\text { South Korea, Australia, countries in } \\
\text { Western Europe and Scandinavia, the } \\
\text { USA }\end{array}$ \\
\hline $\begin{array}{l}\text { Promising countries } \\
\text { for the growth of the } \\
\text { digital economy }\end{array}$ & $\begin{array}{l}\text { despite the relatively low overall level } \\
\text { of digitalization, they are at the peak } \\
\text { of digital development and have the } \\
\text { potential that can enable them to } \\
\text { occupy leading positions, that attract } \\
\text { investors }\end{array}$ & $\begin{array}{l}\text { China, Kenya, Russia, India, Malaysia, } \\
\text { Philippines, Indonesia, Brazil, Colom- } \\
\text { bia, Chile, Mexico }\end{array}$ \\
\hline Countries of concern & $\begin{array}{l}\text { face serious challenges related to low } \\
\text { digital development and slow growth. }\end{array}$ & $\begin{array}{l}\text { South Africa, Peru, Egypt, Greece, } \\
\text { Pakistan }\end{array}$ \\
\hline
\end{tabular}

The most important way to reduce these threats is digital literacy of the population, digital education, and the corresponding professional competencies of enterprises employees. If the gap in the level of well-being of the population can hinder the improvement of digital literacy, then the inadequate understanding of the opportunities and threats of the digital economy by senior management as a result of voluntary or involuntary ignorance can be a barrier to the formation of digital competencies.

Of course, for various reasons, people want to have a universal tool in the development of the digital economy (Ustyuzhanina 2017). However, inclusive development strategies are a set of measures that are more complex than focusing on one, albeit important, relevant and new development factor. In particular, studies show that one of the ways to ensure inclusive development is to identify relevant segmentation of the territory and to identify in each segment the nuclei that produce impulses for the generation and diffusion of innovations (Shapiro 2017)

The digital economy can be compared with an advanced application to the program for scientific society development, for instance modern professions, business or government management of information technology capabilities. ICT tools are designed to free human activity from routine operations, but not to replace it. ICTs make standard operations faster and cheaper, but ICTs are not able to make decisions, especially non-standard ones, not foreseen in any models, programs or other documents. Models and programs systematize, formalize the accumulated experience and extrapolate it for the future. To fulfill the main component in human activity, which goes beyond the use of proven standards and related to decisionmaking, artificial intelligence does not replace human one, it only frees it from performing formal and monotonous operations. In any profession today, there are operations performed from a template by an accountant, a cashier, or a broker who makes payments or transfer money, that is already automated.

But other operations, such as making plans, strategies, developing tax changes, or advising clients (Khaykin 2017), require complex cognitive, economic, social, and communication skills. And the functioning of such professional areas as teaching or performing police functions requires tolerance, patience and prudence, and a certain level of knowledge and wisdom.

The digital economy will not bring benefits if the "analogue" environment is not adapted to a certain progress of events and is not institutionally aimed at inclusive development, when growth in certain segments gives positive effects in all others sectors that are not directly related to it. Otherwise, the digital economy will not only face difficulties while utilizing its advantages, but also may enhance problems and lead to increased inequality and stagnation. 
"Analogue" additions are the legal support of competition, skills of the population, as well as professional competencies that allow the use of new technology and institutions (Lewandowski 2016).

The lack of competition protection against the backdrop of the ICT development leads to an excessive concentration of power in the market and increased monopolization if the company is characterized by the economy of scale, since any monopolization inhibits innovation (Aghion 2015). Competition promotion policies are crucial in this area. It is important to pay attention to such an effective development tools as public-private partnership agreements (Kalgina 2017), regulation of the telecommunications and the Internet functioning. In addition to the complete absence of competition protection, a similar effect can be created with use of protectionism measures, for example, in Panama in 2010, only $25 \%$ of firms used ICTs for electronic commerce, which was caused by a government ban of companies with foreign capital in the retail sector (WDR 2016).

Absence of professional Internet skills will inevitably lead to one of the following facts: the expected increase in labor productivity does not occur or increase in inequality between employees or reduce motivation and so on. It is employees with higher education who receive the greatest amount of positive results from the possession of "digital" skills.

Talking about the ways of providing public services within the framework of digital technologies, there are usually 4 main areas - informing the public and issuing digital identity cards, improving existing bureaucratic procedures, obtaining "feedback", and improving management procedures of state institutions. Informing the population and issuing digital passports instead of traditional ones has the greatest impact on society at the moment (for example, in India this is a very well-developed area). In the world, about 2.4 billion people do not have birth certificates and/or passports, which indicates poorly developed population identification systems in developing countries (World Bank, 2015). However, if the Internet helps to overcome information barriers between officials and citizens in informing about the provision of public services, then there may be problems in receiving feedback - the relevant structures may ignore the information received, which will lead to a drop in trust between the state and the population. Extremely negative results can also be achieved - it is a control of the information sources and its content at the input in a way of more strict censorship. Thus, with the help of public state digital services, problems of weak population awareness and high transaction costs in the public services provision can be solved, as well as information asymmetry in this segment of the digital economy can be reduced.

\subsection{The impact of digitalization on mineral resources management}

But let us turn to the declared topic of mineral resources management and consider what can happen if we do not invest in the digital economy in the field of mineral resources management and the "analogue" correction of institutions.

Subsoil along with soil and water will for a long time be the main raw material for the production of end-use goods, which allow humanity to eat, drink, dress, build housing and lead comfortable life. Subsurface resources are a strategic factor not only for the survival of the countries where they occur, but, ultimately, the foundation of the global economy. Subsoil is an important part of the natural wealth that a person needs as a raw material for production. Rational use of mineral resources is the area of responsibility of those countries where there resources are located (Palyanova et al. 2017).

The Program "Digital Economy of the Russian Federation" [Program "Digital Economy of the Russian Federation" dated July 28, 2017 No. 1632-r Consultant.ru >document/cons_doc_LAW_221756 / . . / ] states that the digital economy is aimed at creating conditions for the development of a knowledge society in Russia, improving the welfare and citizens quality of life by increasing the availability and quality of goods and services produced in the digital economy using modern digital technologies, raising awareness and digital literacy, improving accessibility and quality of public services for citizens, as well as security both domestically and abroad. 
Government programs are expected to be criticized by society, albeit constructive. So the program "Digital Economy of the Russian Federation" caused a lively discussion: in the course of analyzing its goals, content, main areas of work and implementation mechanisms, the importance for solving the problems of socio-economic development, increasing competitiveness in global markets and enhancing national security, many researchers have expressed some concerns (Yakutin 2017). They certainly didn't pay much attention to the mineral resources management.

The literature notes both the positive and negative aspects of the digitalization process in the mineral resources management. In particular, the disadvantages of the digital economy in the field of mineral resources management include: the lack of publicity and the difficulty of obtaining information because the country does not have publicly accessible Internet portals of geological information databases; no open license information; the institutional environment for transactions with subsoil use rights and an objective market assessment of the mining companies assets (state registration of licenses as property) are poorly formed (Zabajkin 2017). This state of affairs leads to a narrowing of the circle of potential investors, complicates the use of geological information by domestic and international companies and investors for market purposes, and complicates the listing of company shares.

It may seem that while total mineral wealth is unknown and reserves are not calculated, the lack of data can serve as informational protection against other potential users.

Digital ignorance in the field of mineral resources management can lead to the fact that the subsoil will be bought up and used outside the control of their owners if they neglect the means of possession of reliable information and relevant knowledge.

Information sources allow us to compare data on the leading countries in the digital economy and the wealth of natural resources (Table 2).

The greater the discrepancy between those countries that have a developed digital economy and countries that own resources, the more information the first countries will have about the second ones and they also can become their actual users, without being formal owners.

Comparison shows that there are few "intersections" in "TOP-10", in this case these are Australia and the USA, but the situation is changing rapidly. The USA was assigned to the second group of countries where the development of the digital economy slowed down, therefore, in "TOP-10" the country is not represented. It is also clear that the level of digitalization in countries that have achieved high results in the development of the digital economy will allow them to have "digital" channels of information about mineral resources and their use in other countries. The development of the digital economy leads to global mineral resources management (Litvinenko 2019). If the countries-owner the subsoil will be "second" in this process, they will have to integrate into those structures and rules that will be established by others.

Table 2. TOP-10 in terms of mineral reserves and the growth rate of the digital economy. Compiled by the authors based on https://newsroom.mastercard.com/digital-press-kits/digital-evolu tion-index-2017/ and http://www.online812.ru/2012/04/28/002/.

\begin{tabular}{lrl}
\hline Resources & & Digital economy \\
\hline Russia & 1 & Singapore \\
The United States of America & 2 & The UK \\
Saudi Arabia & 3 & New Zealand \\
Canada & 4 & The UAE \\
Iran, I.R. & 5 & Estonia \\
China & 6 & Hong Kong \\
Brazil & 7 & Japan \\
Australia & 8 & Israel \\
Iraq & 9 & South Korea \\
Venezuela & 10 & Australia \\
\hline
\end{tabular}


Since Russia is the first country in terms of mineral resources, it should first of all "digitize" its irreplaceable advantages.

"Digitalization of mineral resources management in Russia is a real and concrete process for creating a resource-innovative development model. This process is not opposed to the well-known fact that the main engine of progress and well-being are investments in technology, and not in traditional resources. It logically complements the development strategy of this area, expanding the possibilities of investment policy in technology; it leads to sustainable provision with energy resources; increasing environmental requirements for energy resources and their processing; optimal fuel and energy balance at the regional level and in the whole country; the efficiency of the use of electricity and raw materials", as noted by V.S. Litvinenko, rector of Mining University (Litvinenko 2014).

The digital economy allows us to use such an important competitive advantage as intellectual potential in any field (Vasilenko et al.2020).

The economy is designed so that the leader in new technologies has advantages not only in making profit, but also in setting the rules. If we miss the chance to be the first in the development of the digital economy in the field of mineral resources management, Russia will soon have to integrate into the global mineral resources management according to the rules that are established by others. For example, the economies of countries at the transitional level of development in the digital economy are already facing the difficult task of facilitating and simplifying the international trade. Facilitation is a measure of trade that would have the greatest impact on trade flows and could reduce costs (up to $3 \%$ ).

Of course, mineral resources management is not a virtual process and it is associated with real work and presence on the territory. This means that development of digitization in it may not lead to progress in more "virtual" directions. Risks of being not able to introduce "digital money" in mining segment, from that point of view, are more than real - because it is an unknown concept for traditional mining models. Digitized money is formed as big data sets, where it is stored and, accordingly, can be collected and represented in short time - for example, all property information about economic entities of any level and status (physical, legal, individual, institutional, etc.). New money is becoming extremely informative. The question is not whether or not the information will be used for legal or illegal purposes, but that it will be easy to collect. And then it can be used as an economic resource, which will require correct assessment.

The economy with new, "digitized money" is characterized by a different connection of economic agents. If, as stated in the Report "Obtaining Digital Dividends ..." distances lose importance in the Internet, then the relationship between people, governments and enterprises will become stronger and, moreover, more transparent.

In the context of the digital economy, the profile of information market asymmetries is fundamentally changing, as well as commercial and state secrets take on a different shape. The information asymmetry profile becomes mobile in the sense that not only the seller, but also the buyer of goods and services can possess more information (Lendle 2015), thereby gaining advantages over other buyers or using the ignorance of the seller (Hallward-Driemeier 2015). The asymmetry of information will be determined by the ability or inability of economic agents to handle information flows.

Based on the definition of the economy in the "pre-information era", we can assume that the economy is a monetary system, and the "digitization" of money provides the basis for defining the modern economy as an economy with new, "digitized money".

As noted by J.M. Keynes, money should certainly be included in our conclusions about the real world, and the special properties of money are manifested as a link between the present and the future. Therefore, no one can reliably forecast future changes without understanding of this link - otherwise than in monetary terms (Keynes 1973). The question of what digitized money can do, what their properties are, remains open.

Another important economic problem is the assessment of the information itself. As Andrea Di Mayo, managing vice president of Gartner Research, notes, “... now we measure the value of goods such as oil, but we do not measure the value of the data that will be goods in the digital economy ... In fact, not the real value of the digital economy will be measured, but the way we move towards it. The process of finding ways to measure the digital economy 
requires the participation of not only people involved in ICT, but of those engaged in economic activities" (Di Maio 2017).

One of the important aspects of the issue of digitized money is the issue of security.

\section{DISCUSSION}

Authors would like to highlight the fact that mining industry has been always functioning within information inequality principle and yet nowadays we stand before another problem we have too much information. This leads to a number of peculiarities regarding mining industry financing processes. First, we more often find ourselves in situations with extreme levels of income data unreliability. Secondly, industry is severely disconnected from main price influencers. Lastly, long-term forecasts are dependent on actual observations of market conditions, business psychology etc. Specialists who are trying to work within these peculiarities in industry have to understand that this is an important issue, which has to be solved before we will be able to stabilize processes of natural resources management.

The work carried out to comprehend existing information on the digital economy and its impact on the mining industry was aimed at describing the acute problems of this issue and a rather poor understanding of this process impact on the fundamentals of economic theory the asymmetry of information and the concept of "money". Further research can continue in two directions - changing the theoretical economy under the influence of the digitalization process and the practical sense of it for mineral resources management.

\section{CONCLUSION}

It is possible to apply the general rule of ensuring the efficiency and sustainability of enterprises operating in the mineral resource sector for government participation in solving the problem of digitalization of mineral resources management. This rule states that the lower the efficiency of development and extraction of resources are, the higher the role of the state as a kind of shock absorber of constantly growing economic problems in the field of mineral resources management (Khaykin 2017).

If the state does not actively engage in the digitalization process in the field of mineral resources management, then it may be excluded from real economic processes and sink into informational isolation.

Such a pessimistic forecast for the development of mineral resources management will not come true (although it seems quite realistic) if the sphere of mineral resources management is removed from the peripheral position in digital development, if the policy in this area overcomes the idea that information technology and the digital economy exist parallel to the real world. Attempts to avoid change will only delay, but in no way prevent changes, because new technologies always find a way to overcome barriers, but belated awareness can make changes more difficult for the economy and lead to the loss of the advantages that the country has in the field of mineral resources management today. Reducing investments in the digital economy in mineral resources management today, tomorrow it is possible find yourself in such a virtual innovation environment that getting out of it will be extremely expensive.

\section{ACKNOWLEDGEMENTS}

The reported study was funded by RFBR and MCESSM according to the research project № 19-510-44013\19 


\section{REFERENCES}

Aghion, P., Cai, J., Dewatripont, M., Du, L., Harrison, A. \& Legros, P. 2015. Industrial Policy and Competition. American Economic Journal: Macroeconomics 7 (4): 1-32.

Autor, D., \& Dorn D., 2013. The Growth of Low-Skill Service Jobs and the Polarization of the U.S. Labor Market. The American Economic Review 103 (5): 1553-1597.

Bazhin, V. \& Danilov, I \& Petrov, P.. (2018). Development of automated system based on neural net-work algorithm for detecting defects on molds installed on casting machines. Journal of Physics: Confer-ence Series. 1015. 032025. 10.1088/1742-6596/1015/3/032025.

Bowers, M.R., Hall, J.R. \& Srinivasan, M.M. 2017. Organizational culture and leadership style: The missing combination for selecting the right leader for effective crisis management. Business Horizons 60 (4): July-August, 551-563. URL: http://www.sciencedirect.com/journal/business-horizons/vol/60/ issue/4 (reference date: $25 / 03 / 2018$ ).

Comin, D.A. \& Mestieri, M.F. 2013. If technology has arrived everywhere, why has income diverged? Cambridge: National Bureau of Economic Research. URL: https://www.nber.org/papers/w19010.pdf (reference date: 15/04/2019).

Crozet, M., Milet, E. \& Mirza, D. 2016. The Impact of Domestic Regulations on International Trade in Services: Evidence from Firm-Level Data. Journal of Comparative Economics 44 (3): 585-607.

Czernich, N., Falck, O., Kretschmer, T., \& Woessmann, L. 2011. Broadband infrastructure and eco-nomic growth. Economic Journal, 121(552): 505-532. doi:10.1111/j.1468-0297.2011.02420.x.

Di Maio, A. 2017. Data is fuelling digital economy. Information society 2: 4-8. URL: http://emag.iis.ru/ arc/infosoc/emag.nsf/BPA/3feebdab8714b12f4425818b002f1f6c.

Durrant-Whyte, H., Geraghty, R., Pujol, F. \& Sellschop, R. 2015. How digital innovation can improve mining productivity. URL: https://www.mckinsey.com/industries/metals-and-mining/our-insights/ how-digital-innovation-can-improve-mining-productivity (reference date: 15/04/2019).

Gogolinskiy, K \& Syasko, V. (2019). Prospects and challenges of the Fourth Industrial Revolution for instrument engineering and metrology in the field of non-destructive testing and condition monitoring. In-sight - Non-Destructive Testing and Condition Monitoring. 61. 434 440. 10.1784/insi.2019.61.8.434.

Gomez-Herrera, E., Martens, B. \& Turlea, G. 2013. The Drivers and Impediments for Cross-Border e-Commerce in the EU. Seville: Institute for Prospective Technological Studies. Digital Economy Working Paper 2013/02.

Gruber, H., Hätönen, J., \& Koutroumpis, P. 2014. Broadband access in the EU: An assessment of fu-ture economic benefits. Telecommunications Policy 38(11): 1046-1058. doi:10.1016/j.telpol.2014.06.007.

Hallward-Driemeier, M., \& L. Pritchett. 2015. How Business Is Done in the Developing World: Deals versus Rules. Journal of Economic Perspectives 29 (3): 121-140.

Kalgina, I.S. 2017. Modeli otsenki proyektov gosudarstvenno-chastnogo partnerstva $\mathrm{v}$ sfere nedropol-zovaniya [Models for evaluating projects of public-private partnership in the field of subsoil use]. Zapiski Gornogo instituta 224: 247-254.

Keynes, J.M. 1973. The General Theory of Employment, Interest and Money (1936), Collected Writ-ings 7. URL: https://www.files.ethz.ch/isn/125515/1366_KeynesTheoryofEmployment.pdf (reference date: 15/04/2019).

Khaikin M.M. \& Knysh V.A. 2017b. Yestestvennye monopolii v rossiyskoy ekonomike: vybor modeli regulirovaniya [Natural monopolies in the Russian economy: the choice of regulation model]. Upravlencheskoe konsultirovanie 5 (101): 44-55.

Khaikin, M.M., Knysh, V.A. \& Podolyanets, L.A. 2017a. Industrialno-syrievaya ekonomika: problemy regulirovaniya i upravleniya [Industrial raw materials economy: problems of regulation and manage-ment] St Petersburg: Lema.

Kretschmer, T., Cardona, M., \& Strobel, T. 2013. The Contribution of ICT to Productivity: Key Con-clusions from Surveying the Empirical Literature. Information Economics and Policy 25(3): 109-125. URL: https://doi.org/10.1016/j.infoecopol.2012.12.002 (reference date: 15/04/2019).

Kuznetsov, V.I. \& Khaikin, M.S. 2017. Sotsialno-ekologicheskie aspekty osvoeniya mineralnykh re-sursov mirovogo okeana [Social and environmental aspects of the development of the mineral resources of the oceans]. Zapiski Gornogo instituta 90, June: 55. URL: http://pmi.spmi.ru/index.php/ pmi/article/view/5823. ISSN 2541-9404.

Latif, Z., Mengke, Y., Latif, S., Ximei, L., Pathan, Z.H., Salam Sh. \& Jianqiu, Z. 2018. The dynamics of ICT, foreign direct investment, globalization and economic growth: Panel estimation robust to hetero-geneity and cross-sectional dependence. Telematics and Informatics 35(2): 318-328. doi:10.1016/ j.tele.2017.12.006.

Lederer, M., Knapp, J. \& Schott, P. The digital future has many names: How business process man-agement drives the digital transformation. 6th International Conference on Industrial Technology 
and Management (ICITM). University of Erlangen-Nuremberg. DOI: 10.1109/ICITM.2017.7917889. URL: https://ieeexplore.ieee.org/document/7917889 (reference date: 15/04/2019).

Lendle, A. \& Vézina, P.L. 2015. Internet Technology and the Extensive Margin of Trade: Evidence from eBay in Emerging Economies. Review of Development Economics 19 (2): 375-386.

Lewandowski, P., Hardy, W. \& Keister, R. 2016. Technology or Upskilling? Trends in the Task Composition of Jobs in Central and Eastern Europe. Warsaw: Instytut Badañ Strukturalnych. IBS Working Pa-per 01/2016.

Litvinenko, V. 2014. The future is about investments in technology, and not in resources: Interview with the rector of St Petersburg Mining University on April 12, 2014. Information Agency of St Peters-burg Mining University. URL: http://www.iagorny.ru/novosti/201412/vladimir-litvinenkobudushchee-za-investiciyami-v-tehnologii-ne-v-resursy (reference date: 31/03/2018).

Litvinenko, V.S. 2009. Mineralno-syrievoy kompleks: tekushchaya situatsiya - problemy razvitiya banki [Mineral resources complex: current situation, development problems, and banks]. Dengi i kredit 7: 14-17.

Litvinenko, Vladimir. (2019). Digital Economy as a Factor in the Technological Development of the Mineral Sector. Natural Resources Research. 10.1007/s11053-019-09568-4.

Loch, C.H., Huchzermeier, A., \& Chick, S.E. 2008. Management quality and competitiveness. BerlinHeidelberg: Springer. doi:10.1007/978-3-540-79184-3.

Makhovikov, A.B., Katuntsov, E.V., Kosarev, O.V. \& Tsvetkov, P.S. 2019. Digital transformation in oil and gas extraction. In V. Litvinenko (ed.), Innovation-Based Development of the Mineral Resources Sector: Challenges and Prospects: 11th conference of the Russian-German Raw Materials. St Petersburg: Mining University: 531-538. ISBN: 978-0-367-07726-6.

Manyika, J. et al. 2011. Internet matters: The Net's sweeping impact on Growth, Job and Prosperity. McKinsey Global Institute Report: McKinsey and Company. URL: http://www.mckinsey.com/ insights/high_tech_telecoms_internet/internet_matters (reference date: 15/04/2019).

National Program "Digital Economy of the Russian Federation" dated July 28, 2017 No 1632-p. (In Russian) URL: http://ac.gov.ru/files/content/14091/1632-r-pdf.pdf (reference date: 15/04/2019).

Palyanova, N.V. \& Zadkov, Denis \& Chubukova, S.G.. (2017). Legal framework for the sustainable economic and ecological development in the coal industry in Russia. Eurasian Mining. 2017. 3-5. 10.17580/em.2017.01.01.

Paunov, C., \& Rollo, V. 2015. Overcoming Obstacles: The Internet's Contribution to Firm Development. World Bank Economic Review 29 (Suppl. 1): S192-204.

Prieger, J.E. 2013. The broadband digital divide and the economic benefits of mobile broadband for ru-ral areas. Telecommunications Policy, 37(6-7): 483-502. doi:10.1016/j.telpol.2012.11.003

Revenko, N.S. 2017. Tsifrovaya ekonomika Soedinennykh Shtatov v epokhu informatsionnoy globali-zatsii: aktualnye tendentsii [The US digital economy in the era of information globalization: current trends]. US i Kanada: ekonomika, politika, kultura 8 (572): 78-100.

Schneider Electric Blog. 2018. The modern mine: How digitization is transforming industry from pit to port. URL: https://blog.schneider-electric.com/mining-metals-minerals/2018/11/06/the-modern-minehow-digitization-is-transforming-industry-from-pit-to-port/ (reference date: 15/04/2019).

Shapiro, N.A., Kaplina, Yu.E., Medvedev, E.A. \& Krasnov, E.A. 2017. Theoretical and economic as-pects of the decision of the problem of regional policy in the Russian economy. Economics of sustainable development 4 (32): 222-232.

Tan, Sh.W. 2015. The effects of the Internet on Firm Export Behavior. Background paper for the World Development Report 2016, World Bank, Washington DC.

Tapscott, D. 1995. The Digital Economy: Promise and Peril in the Age of Networked Intelligence. NewYork: McGrawHill.

The Passport of the National Program "Digital Economy of the Russian Federation", approved on December 24, 2018 at a meeting of the Presidium of the Presidential Council for Strategic Development and National Projects under the President of the Russian Federation (In Russian) URL: http://static. government.ru/media/files/urKHm0gTPPnzJlaKw3M5cNLo6gczMkPF.pdf (reference date: 15/04/ 2019).

Trushko V.L., Protosenya A.G. 2019. Perspektivy razvitiya geomekhaniki v usloviyah novogo tekhnologicheskogo uklada. [Prospects of geomechanics development in the context of new technological paradigm]. Zapiski Gornogo instituta 236: 162-166.

Ustyuzhanina, E.V., Sigarev, A.V. \& Shein, R.A. Tsifrovaya ekonomika kak novaya paradigma eko-nomicheskogo razvitiya [Digital economy as a new paradigm of economic development]. Natsionalnye interesy: prioritety i bezopasnost 13, 10 (355): 1788-1804.

Vasilenko, Natalia \& Khaykin, Marck \& Kirsanova, Natalia \& Lapinskas, Arunas \& Makhova, Larisa. (2020). Issues for development of economic system for subsurface resource management in Russia 
through lens of economic process servitization. International Journal of Energy Economics and Policy. 10. $44-48.10 .32479 /$ ijeep.8303.

Vazquez, E.J. \& Winkler, H. 2017. How Is the Internet Changing Labor Market Arrangements? Evi-dence from Telecommunications Reforms in Europe. World Bank, Washington, DC. Policy Research Working Paper No. 7976.

World Bank. 2015. Identification for Development (ID4D) Global Dataset. Washington, DC: World Bank. URL: http://data.worldbank.org/data-catalog/id4d-dataset (reference date: 15/04/2019).

Yakutin, Yu.V. 2017. Rossiyskaya ekonomika: strategiya tsifrovoy transformatsii [Russian Economy: Digital Transformation Strategy]: On Constructive Criticism of the Government Program "Digital Econ-omy of the Russian Federation”. Menedzhment i biznesadministrirovanie 4: 27-52.

Zabaikin, Yu.V., Shenderov, V.I. \& Ibragimov, R.R. 2017. Nedostatki informatsionnogo obe-specheniya nedropolzovaniya Rossijskoj Federatsii [Flaws in subsoil use information system of Russia] Aktualnye problemy i perspektivy razvitiya ekonomiki: rossijskij i zarubezhnyj opyt 7: 92-94. 